\title{
Surface Ordering of a Perfluorinated, Self-Assembled, Dendrimer on Water Subphase
}

Synthesis. The detailed synthetic procedures of the compound are described in Scheme 1. Methyl 3,5-bis(n-5,5,6,6,7,7,8,8,9,9,10,10,11,11,12,12-heptadecafluorododecan-1-yloxy) benzoate (2): A mixture of methyl 3,5-dihydroxybenzoate (1.35 g, $8.02 \mathrm{mmol}$ ) and $\mathrm{K}_{2} \mathrm{CO}_{3}$ (9.47 g, $68.5 \mathrm{mmol}$ ) in $90 \mathrm{ml}$ of DMF was heated to $65^{\circ} \mathrm{C}$ under an $\mathrm{Ar}$ atmosphere. To this was added 1H,1H,2H,2H,3H,3H,4H,4H-perfluorododecyl bromide (1) (10.7 g, 19.2 mmol), and the heterogeneous mixture was then stirred under reflux for 8h. After cooling to room temperature, the reaction mixture was poured into $1 \mathrm{~L}$ ice water and acidified with $10 \%$ $\mathrm{HCl}$. The precipitate was filtered and washed several times with water. The crude product was purified by column chromatography (silica gel, 4:1 hexane/ethyl acetate) to afford 2 as a white powder (7.79 g, yield 89.1\%). ${ }^{1} \mathrm{H} \mathrm{NMR}\left(\mathrm{CDCl}_{3}\right): 1.86\left(\mathrm{~m}, 8 \mathrm{H}, \mathrm{CF}_{2} \mathrm{CH}_{2}\left(\mathrm{CH}_{2}\right)_{2}\right)$, 2.16 (m, 4H, $\mathrm{CF}_{2} \mathrm{CH}_{2}$ ), 3.91 (s, 3H, $\mathrm{COOCH}_{3}$ ), 4.03 (t, 2H, $\mathrm{CH}_{2} \mathrm{OAr}, J=5.69 \mathrm{~Hz}$ ), 6.63 (s, 1H, ArH meta to $\mathrm{COOCH}_{3}$, 4-position), 7.17 (s, 2H, $\mathrm{ArH}$ ortho to $\mathrm{COOCH}_{3}$, 2,6-positions). Methyl 3,5-bis(n-5,5,6,6,7,7,8,8,9,9,10,10,11,11,12,12-heptadecafluorododecan-1yloxy)benzyl chloride (4): A solution of compound 2 (8.92 g, $7.99 \mathrm{mmol})$ in $80 \mathrm{~mL}$ of distilled THF was added dropwise to a stirred suspension of $\mathrm{LiAlH}_{4}(0.329 \mathrm{~g}, 8.85 \mathrm{mmol})$ in $10 \mathrm{~mL}$ of distilled THF. After complete addition, the mixture was stirred for an additional $2 \mathrm{~h}$. The reaction was then quenched by the successive addition of $\mathrm{H}_{2} \mathrm{O}, 15 \%$ $\mathrm{NaOH}$ and $\mathrm{H}_{2} \mathrm{O}$. The as-formed granular solids were then filtered from the organic phase, which was then reduced to dryness on a rotary evaporator, and the resulting product dried under vacuum. The crude product (3) was used in the next step without further purification. 
$\mathrm{SOCl}_{2}(1.33 \mathrm{~g}, 11.1 \mathrm{mmol})$ was added dropwise to a stirring solution of $3(8.75 \mathrm{~g})$ in $50 \mathrm{ml}$ of $\mathrm{CH}_{2} \mathrm{Cl}_{2}$ and $100 \mathrm{ml}$ of THF, containing a catalytic amount of DMF and stirred for 30min. The solvent was removed using a rotary evaporator, and the crude product was purified by column chromatography (silica gel, 2:1 hexane/ethyl acetate) to afford $\mathbf{4}$ as a white solid (5.43g, yield 61.4\%). ${ }^{1} \mathrm{H}$ NMR $\left(\mathrm{CDCl}_{3}\right): 1.85$ (m, 8H, $\left.\mathrm{CF}_{2} \mathrm{CH}_{2}\left(\mathrm{CH}_{2}\right)_{2}\right), 2.17$ (m, 4H, $\mathrm{CF}_{2} \mathrm{CH}_{2}$ ), 3.99 (t, 4H, $\mathrm{CH}_{2} \mathrm{OAr}, J=5.74 \mathrm{~Hz}$ ), 4.50 (s, 2H, $\mathrm{CH}_{2} \mathrm{Cl}$ ), 6.39 (s, $1 \mathrm{H}, \operatorname{ArH}$ meta to $\mathrm{CH}_{2} \mathrm{Cl}$, 4-position), 6.53 (s, 2H, $\mathrm{ArH}$ ortho to $\mathrm{CH}_{2} \mathrm{Cl}$, 2,6-positions).

\section{Methyl 3,5-bis[p-(n-5,5,6,6,7,7,8,8,9,9,10,10,11,11,12,12-heptadecafluorododecan-1-} yloxy) benzyloxy]benzoate (5): Compound 5 was synthesized according to the same procedure described for $\mathbf{2}$. A mixture of methyl 3,5-dihydroxybenzoate ( $0.30 \mathrm{~g}, 1.79 \mathrm{mmol})$ and $\mathrm{K}_{2} \mathrm{CO}_{3}$ (2.04 g, $14.8 \mathrm{mmol}$ ) in $70 \mathrm{ml}$ of DMF was heated to $65^{\circ} \mathrm{C}$ under an $\mathrm{Ar}$ atmosphere. Compound 4 (4.65 g, $6.72 \mathrm{mmol}$ ) was then dissolved in $30 \mathrm{ml}$ of DMF and added to the mixture, which was then refluxed for $16 \mathrm{~h}$ with vigorous stirring. After cooling to room temperature, the reaction mixture was poured into $2 \mathrm{~L}$ ice water and acidified with $10 \% \mathrm{HCl}$. The precipitate was filtered and washed several times with water.

Recrystallization from ethyl acetate gave a white solid (3.65g, yield 88.3\%). ${ }^{1} \mathrm{H}$ NMR $\left(\mathrm{CDCl}_{3}\right): 1.85\left(\mathrm{~m}, 16 \mathrm{H}, \mathrm{CF}_{2} \mathrm{CH}_{2}\left(\mathrm{CH}_{2}\right)_{2}\right), 2.16$ (m, 8H, $\left.\mathrm{CF}_{2} \mathrm{CH}_{2}\right), 3.90$ (s, 3H, $\left.\mathrm{CH}_{3}\right), 3.99$ (t, 8H, $\mathrm{CH}_{2} \mathrm{CH}_{2} \mathrm{CH}_{2} \mathrm{OAr}, J=5.65 \mathrm{~Hz}$ ), 5.00 (s, 4H, $\mathrm{ArCH}{ }_{2} \mathrm{OAr}, 3,5$-positions), 6.39 (s, 2H, ArH meta to $\mathrm{CH}_{2} \mathrm{OAr}$, 4-position), 6.56 (s, 4H, ArH ortho to $\mathrm{CH}_{2} \mathrm{OAr}$, 2,6-position), 6.78 (s, $1 \mathrm{H}, \mathrm{ArH}$ meta to $\mathrm{COOCH}_{3}$, 4-position), 7.28 (s, 2H, $\mathrm{ArH}$ ortho to $\mathrm{COOCH}_{3}$, 2.6positions).

3,5-Bis[p-(n-5,5,6,6,7,7,8,8,9,9,10,10,11,11,12,12-heptadecafluorododecan-1yloxy)benzyloxy] benzoic acid 6, F1A): Compound 5 (3.24 g, $1.40 \mathrm{mmol}$ ) was dissolved 
in a refluxing mixture of $60 \mathrm{ml}$ of THF and $33 \mathrm{ml}$ of EtOH. To the mixture was added 3.3 $\mathrm{ml}$ of $10 \mathrm{~N} \mathrm{KOH}$, and the solution stirred for $5 \mathrm{~h}$ at $65^{\circ} \mathrm{C}$. The reaction mixture was cooled to room temperature and reduced to dryness using a rotary evaporator. The residue was redissolved in $350 \mathrm{ml}$ of THF and acidified with conc. $\mathrm{HCl}$. The heterogeneous mixture was then concentrated on a rotary evaporator and precipitated into $1600 \mathrm{ml}$ of ice water. The precipitate was filtered and the crude product was purified by column chromatography (silica gel, 2:1 hexane/ethyl acetate) to afford $\mathbf{6}$ as a white solid (3.01g, yield 86.6\%). ${ }^{1} \mathrm{H}$ NMR (THF-d): 1.73 (m, 16H, $\left.\mathrm{CF}_{2} \mathrm{CH}_{2}\left(\mathrm{CH}_{2}\right)_{2}\right), 2.17$ (m, 8H, $\left.\mathrm{CF}_{2} \mathrm{CH}_{2}\right), 3.90$ (t, 8H, $\mathrm{CH}_{2} \mathrm{CH}_{2} \mathrm{CH}_{2} \mathrm{OAr}, J=5.83 \mathrm{~Hz}$ ), 4.92 (s, 4H, $\mathrm{ArCH}_{2} \mathrm{OAr}, 3,5$-positions), 6.32 (s, 2H, $\mathrm{ArH}$ meta to $\mathrm{CH}_{2} \mathrm{OAr}$, 4-position), 6.51 (s, 4H, $\mathrm{ArH}$ ortho to $\mathrm{CH}_{2} \mathrm{OAr}, 2$,6-position), 6.72 (s, $1 \mathrm{H}$, ArH meta to $\mathrm{COOCH}_{3}$, 4-position), 7.16 (s, 2H, $\mathrm{ArH}$ ortho to $\mathrm{COOCH}_{3}$, 2.6-positions). 

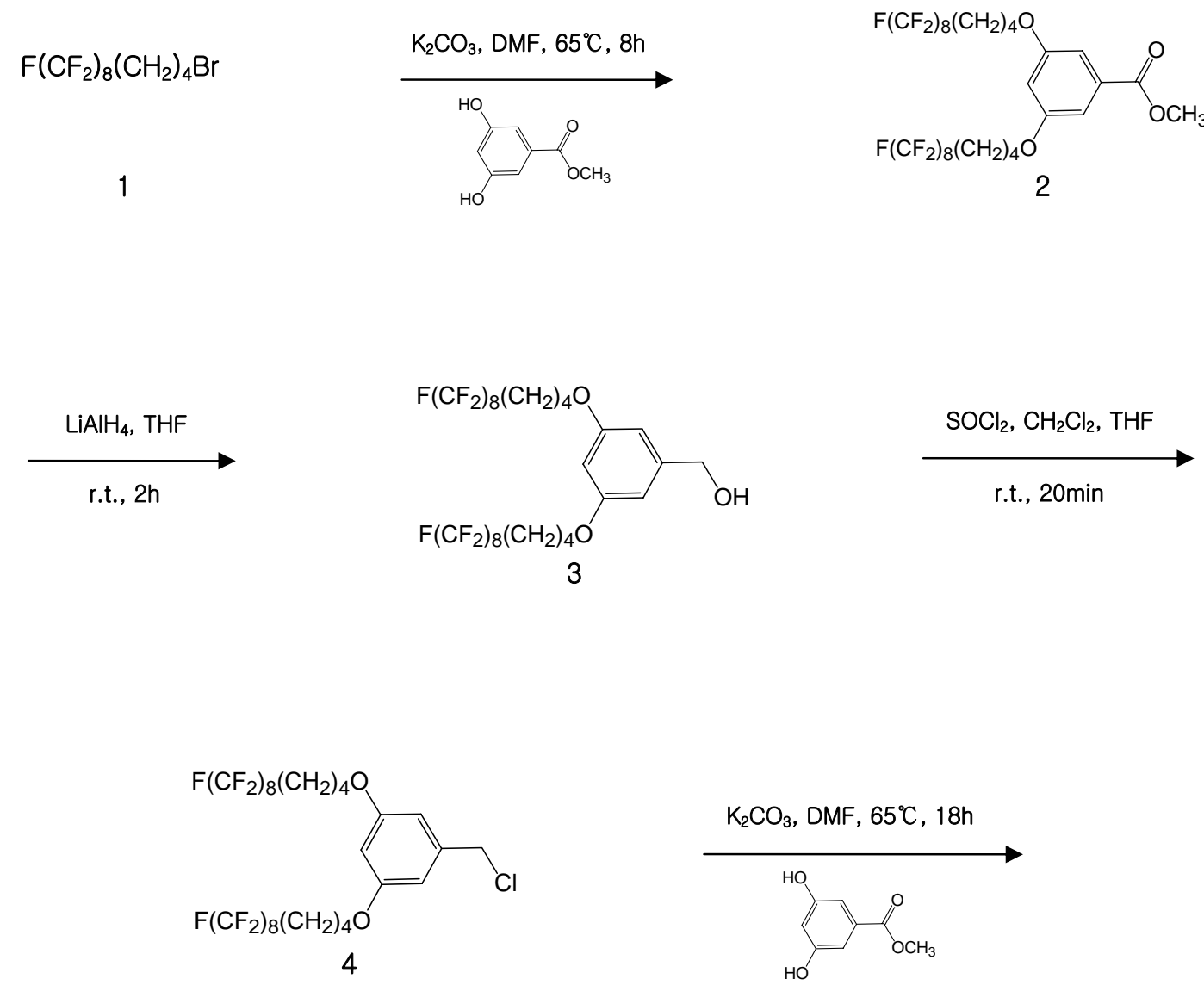

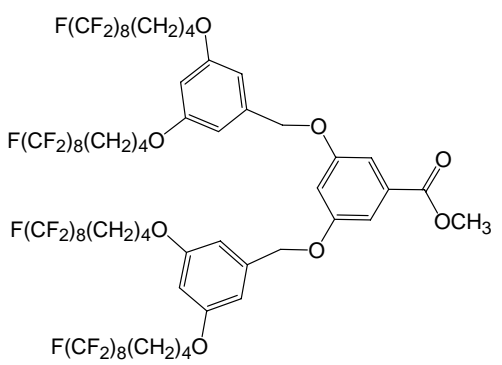

5
1) $\mathrm{KOH}, \mathrm{EtOH}, 4 \mathrm{~h}$

2) $\mathrm{H}^{+}, \mathrm{H}_{2} \mathrm{O} / \mathrm{THF}$

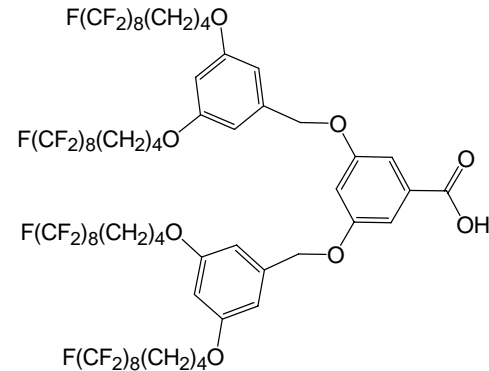

6, F1A

Scheme 1: Synthetic procedure for F1A 